\title{
Pengembangan model manajemen Open Educational Resources (OER) Perpustakaan Institut Agama Islam Negeri Curup
}

\author{
Rahmat Iswanto', Jurianto ${ }^{2}$ \\ 1Program Studi Ilmu Perpustakaan dan Informasi Islam, Institut Agama Islam Negeri Curup \\ ${ }^{2}$ Perpustakaan Institut Agama Islam Negeri Curup \\ Jl. Dr. AK Gani No. 01, Curup, Kabupaten Rejang Lebong, Bengkulu, 39119 \\ e-mail: ${ }^{1}$ rahmatiswanto@iaincurup.ac.id, 2jurianto@iaincurup.ac.id
}

Received: January 2020; Accepted: October 2020; Published: December 2020

\begin{abstract}
Open education resources (OER) are an interesting and diverse source of information that is easily accessible. For the Institut Agama Islam Negeri (IAIN) Curup library, the OER is an alternative service to meet visitors' needs through resources offered are so diverse that it needs adjustment and development. This study was conducted to find out development an effective OER management model to meet IAIN Curup library users' needs. This research used a combination of qualitative and quantitative research types. This study used a research and development method, adoption of the Borg and Gall model. Results showed that the OER management model was selected and developed by testing users' and experts' needs and opinions following the IAIN. OER management model comprised four stages. Stage 1 planning, consisting of steps needs analysis, identification, and verification or preparation. Stage 2 of organizing namely processing activities. Stage 3 actualizing, which consisted of steps service, and promotion. Stage 4 was evaluation. The (OER) management model application was useful. The IAIN Library's OER application could be accessed via a browser at the address http://oer.iaincurup.ac.id; with this open-source platform, and each library could add specific features such as search features, usage statistics, and others. The study concludes that the development of an OER management model for the IAIN Library Curup is still essential so that effectiveness of library services is following the conditions of the community's needs.
\end{abstract}

Keywords: Academic libraries; OER; IAIN Library Curup

\begin{abstract}
Abstrak
Open Educational Resources (OER) adalah sumber informasi yang menarik, bervariasi dan mudah diakses. Bagi Perpustakaan Institut Agama Islam Negeri (IAIN) Curup, OER adalah alternatif pelayanan yang dapat memenuhi kebutuhan pemustaka dengan penawaran beragam sehingga perlu adanya penyesuaian dan pengembangan. Penelitian ini dilakukan untuk mengetahui pengembangan model pengelolaan OER yang efektif untuk memenuhi kebutuhan pemustaka Perpustakaan IAIN Curup. Penelitian ini menggunakan gabungan jenis penelitian kualitatif dan kuantitatif. Metode yang digunakan adalah penelitian pengembangan yang merupakan adopsi dari model Borg dan Gall. Hasil yang diperoleh adalah model manajemen $O E R$ dipilih dan dikembangkan melalui uji kebutuhan, pendapat pemustaka, dan para ahli IAIN Curup. Model manajemen OER terdiri dari 4 tahapan. Tahap 1 perencanaan, terdiri dari langkah analisis kebutuhan, identifikasi, dan verifikasi atau persiapan. Tahap 2 pengorganisasian yaitu kegiatan pengolahan. Tahap 3 actualizing terdiri dari langkah layanan dan promosi. Tahap 4 ialah evaluasi. Penerapan model manajemen OER Perpustakaan IAIN Curup yang telah dikembangkan bernilai efektif. Aplikasi OER Perpustakaan IAIN Curup dapat diakses melalui website di alamat http://oer.iaincurup.ac.id melalui platform open source, dan setiap perpustakaan bisa menambahkan fitur tertentu, seperti fitur pencarian, statistik pemakaian, dan lain-lain. Kesimpulan penelitian adalah pengembangan model manajemen OER bagi Perpustakaan IAIN Curup masih perlu dilakukan agar efektivitas layanan perpustakaan sesuai kebutuhan pemustaka.
\end{abstract}

Kata Kunci: Perpustakaan perguruan tinggi; OER; Perpustakaan IAIN Curup 


\section{PENDAHULUAN}

Proses pendidikan dan pengajaran di masa global dapat didukung melalui sumber informasi berbentuk digital. Informasi yang tersedia melalui media internet kemudian memunculkan sumber pembelajaran daring. Sumber pembelajaran daring ada yang bersifat terbuka yang digunakan untuk tujuan pendidikan, pengajaran, penelitian, dan evaluasi, dikenal dengan Open Educational Resources (OER). Menurut UndangUndang Republik Indonesia Nomor 12 Tahun 2012 Tentang Pendidikan Tinggi (2012), pada pasal 79 ayat 4 tertulis, "Pemerintah mengembangkan sumber pembelajaran terbuka yang dapat dimanfaatkan oleh seluruh sivitas akademika." Pemerintah dalam hal ini mendukung sistem pembelajaran terbuka atau OER yang memudahkan dalam pembelajaran perguruan tinggi.

Sumber daya informasi yang mendukung pelaksanaan kegiatan sivitas akademika tersedia di berbagai media secara luas. Kemajuan teknologi saat ini memungkinkan pemustaka dapat mengakses sumber informasi secara mudah. Perpustakaan sebagai lembaga penyedia sumber daya informasi yang berada di sebuah perguruan tinggi menempatkan dirinya sebagai lembaga penting bagi sivitas akademika. Perpustakaan dirasakan penting oleh pemustaka karena perpustakaan menyimpan sumber daya informasi yang dapat ditemukan dengan mudah dan tepat. Sumber daya informasi yang tersebar luas di media sosial dan media informasi lainnya menawarkan informasi yang masih meninggalkan problematik bagi pemustaka. Informasi terkadang didapatkan sangat banyak, beragam, dan belum tepat. Maka, perpustakaan kemudian menunjukkan perannya dalam penyediaan sumber daya informasi yang cepat dan tepat.

Sivitas akademika dalam pemenuhan kebutuhan informasi melalui pengadaan koleksi tercetak perpustakaan masih memiliki masalah, misalnya kegiatan seleksi dan pengadaan. Kegiatan seleksi, ialah pencarian keberadaan sebuah karya cetak untuk mendukung kajian suatu bidang keilmuan. Kegiatan ini masih memiliki kendala terkait anggaran pembelian yang terbatas. Selain itu, kendala lain adalah berkurangnya persentase pemenuhan kebutuhan pemustaka setiap tahun karena ada kerusakan koleksi, kehilangan, dan koleksi yang tahun terbitnya sudah ketinggalan zaman.

Perpustakaan memiliki fungsi sangat besar dalam pengembangan ilmu pengetahuan karena sumber daya informasi pendidikan untuk masyarakat dapat disediakan secara baik oleh lembaga informasi, seperti perpustakaan (Iswanto \& Sulistyowati, 2018). Terlebih lagi, perpustakaan adalah salah satu lembaga pelayanan informasi yang menerapkan manajemen informasi (pengetahuan) sehingga dalam pengelolaan perpustakaan terdapat penerapan sistem informasi yang mendasar (Fauziyah, 2019). Adapun perpustakaan sudah saatnya berperan sebagai sumber informasi baik tulis maupun bentuk digital. Sumber informasi baik sumber referensi ilmiah, informasi tentang kampus, dan semuanya dapat diakses dengan mudah (Rosyid, 2019).

Perpustakaan di era digital memiliki peran menyediakan open access karena keberadaan teknologi informasi yang dapat membantu penyediaan berbagai bentuk informasi yang diinginkan (Suwarno, 2014). Selain itu, perpustakaan 
berperan besar dalam proses mengorganisasi dan memanajemeni sumber informasi. Pustakawan mengolah informasi dari berbagai sumber kemudian dilayankan kembali pada masyarakat pemustaka yang membutuhkannya. Dengan demikian, banyak usaha yang sudah dilakukan pustakawan agar tujuan perpustakaan dapat memberikan fungsi secara maksimal bagi masyarakat pemustaka (Kristyanto, 2019).

Seyogyanya, pustakawan merupakan partner peneliti dalam melakukan penelitian. Seorang pustakawan harus melek teknologi informasi dalam memenuhi kebutuhan informasi saat pembuatan proposal dan naskah ilmiah (Riyanto, Marlina, \& Triasih, 2019). Berdasarkan sebuah penelitian mengenai pemenuhan kebutuhan pemustaka, tergambar bahwa tingkat pelayanan perpustakaan masih rendah. Hal ini sebagaimana ditunjukkan statistik kunjungan mahasiswa IAIN Curup dengan skor tingkat kunjungan mahasiswa (3.24\%) dan tingkat peminjaman koleksi (38.9\%). Maka perpustakaan harus mengembangkan sumber informasi yang lebih menarik berbentuk digital (Srirahayu, 2019).

Kita melakukan komunikasi era digital melalui bentuk komunikasi email, telepon, dan media sosial. Media sosial hadir dengan tampilan yang beragam dan dapat digunakan secara maksimal demi meningkatkan perkembangan riset. Jaringan antar negara, budaya, maupun antar usia dapat dibentuk melalui media sosial (Irawan et al., 2017). Dengan demikian, pemustaka menghendaki bentuk informasi yang akses informasinya berbentuk digital melalui internet. Perpustakaan kemudian menyediakan layanan seperti Open Educational Resources
(Setiawan \& Ismurjanti, 2018). Pada masa digitalisasi sekarang, alat komunikasi pun ikut berkembang dan lebih canggih. Hal ini sebagai strategi jurnal elektronik dalam mengomunikasikan penulis dan pembaca (pemustaka) (Wibowo, 2019).

Gerakan akses terbuka (open access) dilihat bukan semata-mata sebagai gerakan menggunakan teknologi, gerakan sistem informasi, atau gerakan sistem manajemen. Open access adalah sebuah gerakan kemanusiaan dan memihak kepada kebaikan sebagai kekuatan dasar dari nilai kemanusiaan (Irawan et al., 2018). Maka, perpustakaan dituntut untuk tetap bertahan dengan kemampuan untuk menyesuaikan diri sesuai perkembangan teknologi. Perpustakaan dalam hal ini harus siap dalam menyerap perubahan secara dramatis serta memiliki usaha untuk mengembangkan perpustakaan dalam menghadapi permasalahan (Mulyadi, Zulkarnain, \& Laugu, 2019).

Untuk itu, perpustakaan dapat memberikan solusi dalam memenuhi kebutuhan sumber daya informasi yang mendukung perkuliahan melalui pemberian akses beberapa koleksi digital. Adapun perpustakaan dalam mendapatkan koleksi melalui pembelian secara berlangganan dan kerja sama dengan tenaga pengajar dalam membangun database aplikasi yang mencukupkan kebutuhan secara bertahap. Perpustakaan sebagai lembaga informasi maka dituntut secara cepat memiliki koleksi digital yang dapat diakses pemustaka. Salah satu perpustakaan perguruan tinggi yang menerapkan koleksi digital yakni Perpustakaan IAIN Curup.

Perpustakaan IAIN Curup saat ini sudah mulai memberikan layanan koleksi digital karya institusi atau berlangganan 
database tertentu. Akan tetapi hal ini dirasakan belum cukup untuk meningkatkan pemenuhan kebutuhan sumber daya informasi bagi sivitas akademika. Pemustaka memiliki kebutuhan sumber belajar yang semakin luas mulai dari buku, makalah, dan sumber bentuk elektronik atau komputerisasi. Senada dengan pernyataan Akbar and Noviani (2019) bahwa teknologi di dunia akademik membantu memecahkan masalah sesuai metode atau alat teknologi yang digunakan.

Pendidikan secara luas dipandang sebagai sarana penting untuk mengatasi masalah nasional dan internasional, seperti ekstremisme politik atau agama, kemiskinan, dan kelaparan. Jika negara berkembang ingin bersaing dengan negara barat, maka negara berkembang hendaknya melakukan perubahan berpikir mengenai nilai dan kebutuhan pendidikan untuk lebih baik. Salah satu prosesnya ialah pengembangan sumber informasi terbuka agar dapat dicapai masyarakat dengan lebih mudah.

Masyarakat yang beragam memberikan peluang dalam pelaksanaan media OER. Prinsip desain awal yang lebih baik untuk memungkinkan pemustaka menggunakan OER pemustakaan sesuai konteks lingkungan yang berbeda (Richer \& McPherson, 2012). Indonesia sebagai salah satu negara berkembang mencoba meningkatkan pendidikan melalui teknologi yang mumpuni. Walaupun demikian, kondisi Indonesia pun tidak jauh berbeda dengan negara lain yang masih mencoba mengembangkan dan meningkatkan pendidikan di masyarakatnya, misalnya penelitian hasil anak bangsa.

"Secara global kebebasan akses informasi sangat dilegalkan jika tujuannya bersifat ilmiah bukan komersial. Selain itu, banyak penelitian yang dibiayai oleh pemeritah terutama dalam proyek hibah penelitian seharusnya dapat dipastikan telah disebarluskan melalui internet tanpa adanya batasan tertentu" (Asmad et al., 2018).

Penelitian merupakan hasil dari pendidikan. Kemajuan teknologi membantu menyebarluaskan penelitian ke masyarakat untuk diakses secara terbuka. Indonesia dengan negara lain pun sedang mencoba membagikan pengetahuan yang diperoleh melalui teknologi sehingga pemustaka dari luar negara dapat mengaksesnya. Selain penelitian, proses belajar dalam pendidikan pun sekarang mulai dipraktikkan beberapa perguruan tinggi. Universitas Terbuka (UT) telah menerapkan OER cukup baik walau masih terbatas dalam bahasa. Sistem OER menampilkan bahasa Inggris dan bahasa Indonesia untuk komunikasi pemustaka. Namun sebagian besar pemustaka yakni dosen terbiasa memilih pengaturan bahasa Indonesia.

Berdasarkan hasil penelitian Muganda, Samzugi, and Mallinson (2016) mengenai penerapan OER di African Open Distance and eLearning (ODeL) masih memiliki kendala pada staf. Staf belum memiliki keahlian, kompetensi dalam mengkreasikan, mengintegrasikan, dan menggunakan OER. Maka, lembaga dalam mengembangkan OER membuat panduan penggunaan OER bagi staf sesuai kebijakan lembaga. Pada perkembangan terakhir, OER telah dilakukan dan dikembangkan banyak lembaga dunia. Mtebe and Raisamo (2014) menambahkan bahwa OER dikenalkan United Nations Educational, Scientific and Cultural Organization (UNESCO) pada Forum on the 
Impact of Open Courseware for Higher Education in Developing Countries $2002 \mathrm{di}$ Perancis. Forum ini membantu memenuhi sumber daya informasi pada negara berkembang melalui OER, misalnya Organization for Economic Co-operation and Development (OECD), the William and Flora Hewlett Foundation, the Commonwealth of Learning (COL), dan UNESCO.

Sesuai rujukan ini, UNESCO dan beberapa organisasi telah mengembangkan pendidikan OER melalui dukungan sumber informasi berupa pelatihan, modul pelatihan, video pembelajaran, simulasi pengerjaan tugas, dan buku ajar elektronik. Hal ini menandakan bahwa perkembangan OER khususnya wilayah Asia dapat digolongkan dari negara yang masih tahap penerapan, contohnya negara Indonesia, Malaysia, dan Filipina, sedangkan negara mapan, seperti di Jepang, Hongkong dan Cina. Indonesia sendiri OER masih dalam tahap berkembang, di mana pandangan dan penguasaan para akademik dan profesional masih sebatas kebijakan. Universitas Terbuka sebagai salah satu penggerak OER di kawasan Asia dan juga di dunia perlu untuk menerapkan konsep OER dalam pelaksanaan pendidikan jarak jauhnya (Abeywardena \& Gajaraj, 2012).

Sistem OER tidak identik dengan pembelajaran daring. Konten yang dilisensikan secara terbuka dapat diproduksi berbagai media, di antaranya teks berbasis kertas, video, audio, dan multimedia berbasis komputer. Muganda et al. (2016) pun menjelaskan bahwa jenis OER di African Open Distance and eLearning (ODeL) berupa buku teks atau diktat kuliah, tutorial, hasil kerja kelompok, dan bentuk lainnya. Koleksi pembelajaran menggunakan $O E R$ dapat bersumber dari teks, elektronik, atau digital. Media OER memiliki sumber daya terbuka yang diproduksi untuk dapat dibagikan dalam format digital dan dicetak. Maka, beberapa negara berkembang masih memiliki kendala bandwidth dan konektivitas. Sistem OER yang terencana diharapkan dapat meningkatkan persentase sumber daya agar relevan dengan pendidikan tinggi di negara tersebut.

Bidang pendidikan yang dibangun setiap profesi, disiplin akademis, dan masyarakat pada umumnya menggunakan penelitian untuk mengembangkan pengetahuan. Penelitian menghasilkan informasi dan pengetahuan baru. Maka, dalam bidang pendidikan,

"Peserta didik dan guru harus memiliki akses teknologi digital di dalam lingkungan lembaga pendidikan. Adanya materi yang berkualitas dan bermanfaat bagi guru dan peserta didik. Guru harus memiliki pengetahuan dan keterampilan dalam menggunakan media pembelajaran digital untuk membantu siswa agar mencapai standar akademik dan mengembangkan potensinya" (Akbar \& Noviani, 2019).

Mahasiswa dan dosen di perguruan tinggi harus memiliki pengetahuan dalam menggunakan fasilitas teknologi pendidikan. Salah satunya ialah Massive Open Online Courses (MOOCs) yang terdiri dari pelajaran yang dapat diakses secara bebas terutama peserta didik di internet. Sebagian besar peserta didik tidak mengikuti kursus ini secara penuh, hanya berpartisipasi sesuai kebutuhan dan preferensi pribadi. Lembaga MOOCs telah tumbuh dari gerakan pembelajaran online dan mulai menggunakan lisensi tertutup. Lembaga ini berbeda dengan lembaga 
lainnya yang biasanya kegiatan mencari laba. Lembaga MOOCs memiliki modal usaha yang didukung dan ditandai fokus lembaga dalam mentransmisikan pengetahuan, misalnya kuliah melalui video daripada interaksi. Lembaga MOOCs menekankan konektivitas dan mengandalkan penemuan, diskusi, dan penciptaan pengetahuan bersama di antara para peserta sehingga lembaga ini menggunakan konten yang memiliki lisensi terbuka yakni dapat diakses secara bebas di internet (McGreal, 2013).

Adji (2014) dalam penelitiannya mengatakan bahwa, panduan daring sebagai salah satu bantuan proses belajar yang digunakan UT pada mahasiswanya. Hal ini bertujuan menyampaikan berbagai informasi mengenai pelayanan OER. Suatu data didapatkan dari hasil aktivitas diskusi dan pelaksanakan tugas tutorial oleh mahasiswa menggunakan indikator pemanfaatan OER. Hasil penelitian ini menyatakan bahwa, pertama, pembelajaran menggunakan OER sesuai teori belajar connectivism. Kedua, tutor menunjukkan OER pada mahasiswa melalui Rancangan Aktivitas Tutorial (RAT), Satuan Aktivitas Tutorial (SAT), dan materi tutorial daring. Ketiga, mahasiswa peserta tutorial daring yang menggunakan OER pada pelaksanaan tugas tetapi tidak mengikuti proses diskusi memiliki persentase sejumlah $86 \%$ responden. Keempat, mahasiswa menggunakan OER digunakan untuk menjawab pertanyaan mengenai penjelasan konsep dan belum banyak mahasiswa yang menggunakan OER untuk menyusun suatu pendapat.

IFLA (2019) menambahkan bahwa OER bukanlah sistem terpusat, walaupun di dalamnya terdapat beberapa koordinasi dan inisiatif yang berbeda. Istilah OER pertama kali diadopsi di Forum 2002 UNESCO tentang dampak Open Courseware untuk pendidikan tinggi di negara Berkembang. Organisasi internasional, pemerintah regional, pemerintah nasional telah mengeksplorasi dan dalam kesempatan tertentu mendorong penciptaan dan pelayanan OER. Beberapa organisasi, di antaranya perpustakaan dan badan penelitian, seperti Creative Commons, telah terlibat dalam upaya advokasi untuk memengaruhi kebijakan di seluruh dunia.

Salah satu model penyediaan sumber daya informasi adalah sumber pembelajaran terbuka, atau dikenal Open Educational Resources (OER). Model ini sudah digunakan dalam proses pembelajaran di UT dan ternyata membutuhkan suatu manajemen dan pengaturan tersendiri. Perpustakaan perguruan sendiri berfungsi sebagai media pengembang $O E R$ untuk dapat digunakan para pemustaka. Indrajit (2018) pun berpendapat bahwa perpustakaan mempunyai tugas penting dalam sistem OER di dunia. Perpustakaan menyediakan sumber informasi dari pelbagai media yang dapat diakses mudah pemustaka. Sesuai temuan pra penelitian di Perpustakaan IAIN Curup, peneliti memandang bahwa perlu diadakan penelitian mengenai model manajemen OER pada Perpustakaan IAIN Curup. Maka penelitian ini bertujuan untuk mengetahui model manajemen OER, pengembangan model manajemen OER, dan efektivitas penerapan model manajemen OER.

\section{METODE PENELITIAN}

Penelitian ini menggunakan jenis penelitian yang menggabungkan penelitian kualitatif dan kuantitatif. 
Adapun jenis penelitian yang digunakan ialah penelitian pengembangan. Sugiyono (2016) mengatakan bahwa penelitian pengembangan adalah metode yang digunakan untuk mendapatkan produk tertentu dan pengalaman yang efektif.

$$
\text { Adapun model penelitian }
$$
pengembangan yang digunakan dalam penelitian ini adalah mengadopsi model Borg dan Gall yang kemudian hanya melakukan uji coba satu kali. Sumber data penelitian ini terbagi dua, yaitu sumber primer dan sumber sekunder. Sugiyono (2016) menyatakan bahwa sumber primer bersumber dari responden langsung sesuai masalah yang diteliti, misalnya wawancara. Selain itu, peneliti dalam teknik pengumpulan data membuat dan menyebarkan angket, melakukan Focus Group Discussion (FGD), dan melakukan tes uji coba. Peneliti mewawancarai responden yang terdiri dari pemustaka, pustakawan, dan tenaga pengajar IAIN Curup kemudian mencatat data penelitian yang dibutuhkan. Adapun populasi penelitian adalah masyarakat pemustaka Perpustakaan IAIN Curup yang aktif berkisar 4000 pemustaka dan sampel yang digunakan untuk merespons dengan taraf kesalahan 5\% yaitu sejumlah 351 responden. Kegiatan wawancara merupakan dialog yang dilakukan peneliti dengan responden untuk mendapatkan sumber informasi yang bertanggung jawab. Wawancara sebagai pendekatan dalam menemukan fakta melalui tanya jawab, misalnya peneliti mengajukan beberapa pertanyaan yang diarahkan secara sistematis pada permasalahan. Peneliti melakukan wawancara untuk mengumpulkan pernyataan tentang fenomena di lapangan, melalui sikap dan wawancara.

Selain itu, peneliti membuat angket sebagai salah satu alat sumber data yang berkaitan dengan ilmu sosial dan sumber akses informasi, persepsi, atau pendapat individu. Peneliti menggunakan angket mengenai kebutuhan literatur dan bentuk model manajemen OER yang dikembangkan. Maka peneliti menyediakan banyak waktu dan upaya dalam membuat angket agar lengkap dan sesuai pertanyaan penelitian.

Peneliti dalam penelitian ini juga melaksanakan FGD dalam rangka mengumpulkan data yang dibutuhkan. Data yang diperoleh adalah kesimpulan dari beberapa pembahasan dalam FGD yang kemudian melalui pencatatan hasil diskusi data digunakan sesuai dengan kebutuhan. Adapun tes adalah serangkaian rangsangan (verbal, tertulis, gambar, atau menggambar pertanyaan) yang disiapkan untuk mengukur secara kuantitatif atau perilaku dan tes memberikan derajat atau peringkat kepada penguji. Tes dapat berupa instrumen khusus. Uji coba pada penelitian ini dilakukan kepada kelompok kecil dan besar untuk menilai manajemen OER.

Peneliti pun melakukan tahap analisis, proses pengorganisasian fakta untuk dapat ditafsirkan. Proses analisis yang dilakukan yaitu menggunakan dua jenis analisis, kualitatif dan kuantitatif. Analisis kualitatif adalah kegiatan yang berhubungan dengan pengolahan data, pembagian, dan pengelompokan data secara teratur. Peneliti dapat menafsirkan data, mengeluarkan dimensinya, menentukan urgensi, dan menemukan maksud lain yang bermanfaat. Pada pendapat lain, analisis kualitatif adalah kegiatan penelitian dan penyusunan faktafakta yang ditemukan dari wawancara, secara sistematis sehingga memudahkan 
pemahaman dan mendapatkan informasi lainnya (Sugiyono, 2016). Peneliti membuat deskripsi dari analisis hasil wawancara tentang model manajemen OER menggunakan model yang dikembangkan dari sisi prinsip, susunan, dan efektivitasnya.

Peneliti dalam metode penelitian kuantitatif melakukan analisis hasil angket dan uji coba melalui analisis statistik dengan ukuran standar tertentu. Peneliti menggunakan rumus Sukardjo (2012).

$$
\begin{array}{rll}
\mathrm{X} & =\frac{\sum \mathrm{x}}{\mathrm{N}} \\
\mathrm{X} & = & \text { Rata-rata } \\
\sum x & = & \text { Jumlah skor Responsden } \\
\mathrm{N} & = & \text { Jumlah Responsden }
\end{array}
$$

Untuk memberikan nilai mengenai model manajemen OER, maka peneliti menggunakan ukuran penilaian standar 5 sesuai tabel 1, di antaranya ukuran $\mathrm{X}>$ $4,21,3,40<X \leq 4,21,2,20<X \leq 3,40,1,79<$ $X \leq 2,20, X \leq 1,79$, dengan nilai sangat baik, baik, cukup, kurang, dan lemah.

\begin{tabular}{|c|c|c|c|}
\hline Pilihan & Ukuran & Nilai & Keterangan \\
\hline A & $X>4,21$ & $\begin{array}{l}\text { Sangat } \\
\text { Baik }\end{array}$ & $\begin{array}{l}\text { tidak perlu } \\
\text { perbaikan }\end{array}$ \\
\hline B & $\begin{array}{l}3,40<X \leq \\
4,21\end{array}$ & Baik & $\begin{array}{l}\text { tidak perlu } \\
\text { perbaikan }\end{array}$ \\
\hline $\mathrm{C}$ & $\begin{array}{l}2,20<X \leq \\
3,40\end{array}$ & Cukup & $\begin{array}{l}\text { perlu } \\
\text { perbaikan }\end{array}$ \\
\hline $\mathrm{D}$ & $\begin{array}{l}1,79<X \leq \\
2,20\end{array}$ & Kurang & $\begin{array}{l}\text { perlu } \\
\text { perbaikan }\end{array}$ \\
\hline $\mathrm{E}$ & $X \leq 1,79$ & Lemah & $\begin{array}{l}\text { perlu } \\
\text { perbaikan }\end{array}$ \\
\hline
\end{tabular}

\section{Tabel 1}

Tingkat ukuran dengan standar 5 untuk menganalisis model manajemen yang dirancang

Sumber: Sukardjo, 2012

Kemudian peneliti menggunakan indikator dari Sugiyono (2016) menggunakan indikator standar 5 untuk menganalisis secara kualitatif model manajemen yang dirancang berupa indikator setuju sekali/efektif sekali, setuju, ragu-ragu, tidak setuju, dan tidak setuju sekali.

Tabel 2

Indikator standar 5

\begin{tabular}{ll}
\hline Nilai & Indikator \\
\hline 5 & Setuju sekali/efektif sekali \\
4 & Setuju \\
3 & Ragu-ragu \\
2 & Tidak setuju \\
1 & Tidak setuju sekali
\end{tabular}

Sumber: Sugiyono, 2016

\section{HASIL DAN PEMBAHASAN}

Manusia memerlukan informasi untuk memecahkan masalah dalam hidupnya, termasuk pendidikan, pekerjaan, atau organisasi. Saat ini, informasi telah membantu dan mendukung hampir semua aktivitas manusia melalui teknologi ilmu komputer sebagai alat bantu pengolah data ke informasi. Maka pekerjaan manajemen informasi suatu organisasi yang awalnya sulit mengalami perubahan ke arah yang mudah. Pekerjaan informasi seperti pekerjaan lain harus dikerjakan berdasarkan prinsip konsep manajemen agar pekerjaan lebih terarah dan mencapai tujuan secara maksimal.

Kegiatan manajemen OER adalah kegiatan yang termasuk dalam cabang Ilmu Manajemen Sistem Informasi (MSI). Pekerjaan mengelola informasi yang memanfaatkan prosedur yang berlandaskan kepada prinsip manajemen informasi. Kegiatan manajemen sendiri adalah kegiatan manusia dalam mengelola sumber daya manusia, material, dan metode atau yang lebih dikenal dengan $3 \mathrm{M}$, di antaranya man, material, dan method.

Manajemen sistem informasi sendiri muncul seiring kemajuan teknologi 
informasi yang berdampak pada munculnya beragam informasi yang membutuhkan pengelolaan sehingga dapat dimanfaatkan sesuai tujuan. Pengelolaan OER dapat dicapai secara efisien dan efektif apabila fungsi manajemen, seperti perencanaan, pengorganisasian, pengarahan, dan pengawasan dapat diaplikasikan. Kemajuan teknologi membawa dampak yang besar bagi dunia pendidikan. Sumber-sumber pembelajaran dari pelbagai disiplin ilmu sangat mudah diakses dan dimanfaatkan peserta didik. Hal ini didukung teknologi internet yang memungkinkan informasi dapat tertransmisikan dengan cepat melalui jaringan. Di sisi lain, banyak hal negatif yang terjadi dalam pemanfaatan informasi, contohnya tindakan plagiat atau pelanggaran hak cipta, pemanfaatan karya orang lain yang tidak memenuhi kaidah akademik dalam hal pengutipan dan penulisan daftar pustaka.

Sumber pembelajaran terbuka pun tidak terlepas dari hal ini. Pemanfaatan OER meskipun sifatnya terbuka dalam penulisan karya akademik tetap harus mengikuti kaidah yang berlaku. Perkembangan teknologi saat ini seorang penulis dapat menggunakan reference manager seperti Zotero, Mendeley, RefMan, EndNote, dan lain-lain untuk membantu mengelola referensi dan pembuatan daftar pustaka. Oleh karena itu, penting sekali sumber pembelajaran terbuka dikelola dengan baik melalui sebuah manajemen OER yang baik karena berdampak langsung pada pengambilan metadata pada saat proses pengutipan melalui reference manager.

Pengelolaan OER di sebuah institusi dibutuhkan sebuah platform Learning Managemen System (LMS) sebagai sebuah perangkat lunak yang memungkinkan pustakawan mengelola sumber pembelajaran, mulai tahap input data, pengorganisasian metadata, proses publikasi, hingga akses sumber belajar. Saat ini banyak sekali aplikasi berbasis LMS yang dikembangkan institusi dan komunitas open source. Sesuai hasil FGD yang peneliti lakukan, ada beberapa aplikasi yang memang didesain sebagai LMS dan memiliki lisensi open source, di antaranya Moodle, Cloroline, dan Omeka.

Setelah peneliti melakukan uji coba instalasi, peneliti memutuskan menggunakan dan mengembangkan pengelolaan OER menggunakan Omeka. Aplikasi ini digunakan untuk mengembangkan model manajemen OER di Perpustakaan IAIN Curup berdasarkan beberapa keunggulan yang dimiliki Omeka dibandingkan aplikasi sejenis. Sesuai hasil FGD, aplikasi Omeka memiliki lisensi penerbitan secara gratis dan open source untuk lembaga pendidikan, seperti sekolah dan perguruan tinggi untuk para pustakawan, arsiparis, museum profesional, dan penggemar budaya. Aplikasi Omeka pun memiliki struktur lengkap skema metadata Dublin Core yang dapat dijalankan menggunakan model koleksi digital yang tersedia saat ini.

Selain itu, Omeka memiliki elemen untuk mengatur manajemen dan metadata yang lengkap. Pertama, fitur migrasi data, OAI-PMH harvester dan CSV importer yang memungkinkan dapat disatukan dalam katalog bersama onesearch.id yang dikembangkan Perpustakaan Nasional R.I., dengan standar W3C, 508 compliant, yang sangat dibutuhkan untuk pertukaran data antar perpustakaan menggunakan aplikasi sejenis. Kedua, fitur improved exhibit building, yang sangat dibutuhkan pustakawan dalam mempromosikan 
koleksi melalui fitur ini.

Ketiga, fitur tema yang memberikan kemudahan memilih, mengembangkan, atau menyusun bentuk website sendiri berdasarkan kebutuhan perpustakaan. Selain itu, fitur ini dapat memunculkan dan memperbarui label pilihan dalam menggambarkan tampilan jenis data yang tidak sama saat pemustaka menggunakan layanan. Keempat, fitur otomatis saat penandaan mendorong pemustakaan secara standar, di antaranya ada fungsi Web 2.0, konten sindikasi dengan RSS feed, item tag dengan kata kunci, dan personalisasi item favorit. Kelima, fitur mengajak dan menambahkan pemustaka untuk berbagi dalam penyusunan konten dan kerja sama, seperti plugins, geolocation, konten yang dibuat pemustaka, bookmark sosial, dokumen browsing, batch uploading, dan penyesuaian sesuai kebutuhan.

Aplikasi Omeka bisa didapatkan secara gratis di www.omeka.org. Sesuai keunggulan di atas, maka aplikasi ini memenuhi syarat untuk dijadikan sebuah platform pengelolaan sumber pembelajaran terbuka atau OER yang diperuntukan untuk pemustaka di IAIN Curup, khususnya pemustaka secara luas. Perpustakaan IAIN Curup penting sekali memiliki model manajemen OER. Berdasarkan hasil wawancara yang dilakukan peneliti kepada pemustaka perpustakaan menghasilkan temuan sebagai berikut. Pertama mengenai kebutuhan. Responden yang diwawancarai menyatakan bahwa koleksi Perpustakaan IAIN Curup masih memerlukan tambahan karena pemustaka sering tidak mendapatkan sumber informasi yang dibutuhkan. Hal ini menguatkan peneliti bahwa layanan OER diharapkan mampu menambah kebutuhan pemustaka. Kedua mengenai media yang menarik bagi pemustaka. Layanan OER adalah layanan yang menarik karena bentuknya menggunakan akses teknologi. Hal ini diperkuat melalui jawaban responden. Ketiga mengenai harapan model OER. Model layanan OER bagi pemustaka adalah yang penting tersedia, mudah digunakan, dan memuat informasi yang dibutuhkan.

Adapun berdasarkan hasil angket yang dilakukan peneliti kepada 351 pemustaka mengenai kebutuhan tambahan penyediaan koleksi maka didapatkan hasil sebagai berikut. Pertama, variabel kebutuhan dari angket pemustaka menjawab $40 \%$ sangat setuju, 30\% setuju, $28 \%$ tidak mengetahui, dan $2 \%$ tidak setuju bahwa mereka masih membutuhkan koleksi tambahan. Dengan demikian, koleksi sangat dibutuhkan sehingga layanan OER diharapkan sangat berperan dalam pemenuhan kebutuhan informasi. Pemustaka berpendapat bahwa pemustaka yang masih belum mendapatkan buku di perpustakaan sebanyak 34\% sangat setuju, 28\% setuju, $13 \%$ tidak mengetahui, dan 25\% tidak setuju. Dengan demikian, perpustakaan harus lebih gencar memenuhi kebutuhan pemustaka. Pemustaka sendiri sangat tertarik mencari buku di media online sesuai hasil angket yang mengatakan sangat setuju $55 \%$, setuju 32\%, tidak mengetahui $8 \%$, dan tidak setuju $5 \%$. Layanan OER diharapkan dapat perhatian yang cukup baik.

Variabel kedua, OER adalah media yang menarik. Pemustaka memberikan tanggapan terkait dengan layanan OER apakah layanan merupakan layanan yang menarik, yaitu 65\% sangat setuju, 10\% setuju, 25\% tidak mengetahui. Variabel ketiga mengenai model OER yang diharapkan. Menurut pemustaka, layanan 
OER harus menarik meskipun tidak banyak jumlah. Maka pemustaka memberikan respons 30\% sangat setuju, $16 \%$ setuju, 20\% tidak tahu, dan 34\% tidak setuju. Maka layanan OER diharapkan menarik dan memiliki koleksi yang cukup. Adapun menurut pemustaka, layanan OER harus memiliki banyak koleksi meskipun tidak menarik, pemustaka memberikan respons $15 \%$ sangat setuju, $16 \%$ setuju, 30\% tidak tahu, dan 39\% tidak setuju. Dengan demikian, layanan OER diharapkan memiliki koleksi yang cukup menarik. Sementara itu, pemustaka yang ditanya pendapatnya mengenai jumlah koleksi layanan yang banyak maka pemustaka memberikan respons $76 \%$ sangat setuju, $20 \%$ setuju, dan $4 \%$ tidak mengetahui.

Berdasarkan hasil wawancara yang dilakukan peneliti kepada kepada 3 orang pustakawan Perpustakaan IAIN Curup melalui pertanyaan, "Menurut Saudara, bagaimana memberikan memberikan pelayanan OER yang baik"?, maka didapatkan hasil bahwa pustakawan dalam memberikan pelayanan OER ingin mendapatkan penugasan khusus disertai fasilitas yang memadai. Di samping itu, pustakawan mengharapkan proses kegiatan harus jelas dan dapat dilakukan dengan mudah atau tidak rumit. Adapun berdasarkan hasil angket yang dilakukan peneliti kepada pustakawan perpustakaan, maka didapatkan hasil sebagai berikut. Pertama pustakawan menyatakan 75\% sangat setuju jika model tahapan dalam membuat pelayanan OER IAIN Curup harus mudah dan $25 \%$ pustakawan setuju. Sementara pustakawan 50\% berpendapat setuju jika tahapan dalam membuat pelayanan OER IAIN Curup harus dilakukan oleh petugas khusus dan 50\% pustakawan menyatakan tidak mengetahui. Pustakawan sejumlah 100\% sangat setuju jika tahapan dalam membuat pelayanan OER IAIN Curup harus sesuai proses kepustakawanan.

Peneliti setelah melakukan kajian pustaka, pengumpulan data, dan analisis, kemudian melakukan Focus group Discusion (FGD). Peneliti dalam FGD melibatkan tim Teknologi Pangkalan Data (TIPD) IAIN Curup, yaitu Unit Teknologi Informasi dan seluruh Pustakawan IAIN Curup, membahas strategi pengelolaan OER dan pemilihan software. Hasil FGD sepakat bahwa pengelolaan sumber pembelajaran terbuka di IAIN Curup menggunakan aplikasi Omeka. Aplikasi ini memungkinkan sebuah perpustakaan mengembangkan pengelolaan OER sesuai kebutuhan masing-masing perpustakaan. Aplikasi OER Perpustakaan IAIN Curup dapat diakses melalui website di alamat http://oer.iaincurup.ac.id. Hadirnya platform open source di setiap perpustakaan dapat menambah fitur tertentu, seperti fitur pencarian, statistik pemakaian, dan lainlain.

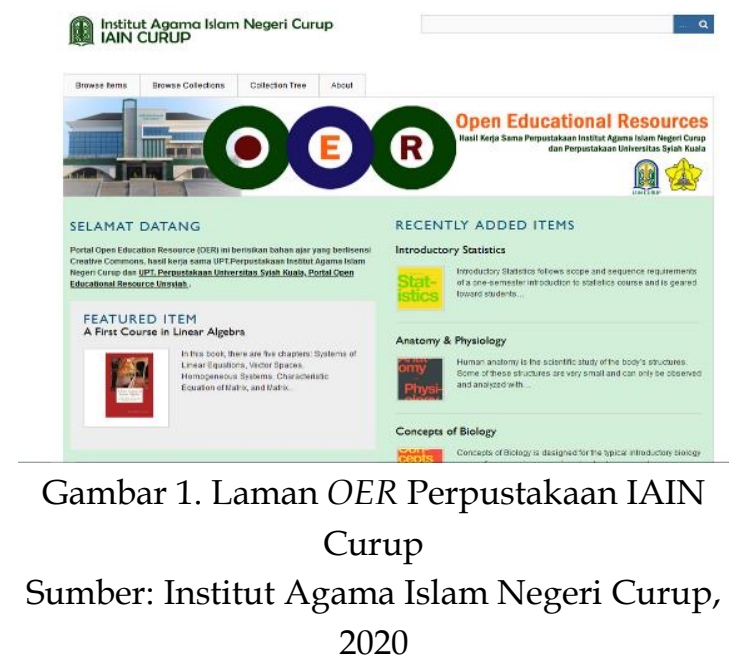

Model pengelolaan OER di Perpustakaan IAIN Curup memiliki tahapan yang harus dilakukan di antaranya, tahap perencanaan atau persiapan, tahap pengorganisasian, tahap 
pengelolaan, pelayanan (actualizing), dan tahap evaluasi. Tahap perencanaan terdiri dari 3 langkah, yaitu analisis kebutuhan, identifikasi, dan verifikasi. Pertama analisis kebutuhan (need assesment) dilakukan agar koleksi yang terkumpul dalam OER memiliki manfaat yang maksimal. Analisis kebutuhan berfungsi mengidentifikasi kebutuhan sumber belajar yang belum atau sudah dimiliki masing-masing prodi di IAIN Curup.

Perpustakaan untuk mengenali kebutuhan koleksi sumber belajar dapat melakukan pemetaan pada mata kuliah masing-masing prodi dan membuat daftar ketersediaan dan kebutuhan koleksi. Perpustakaan setelah menyusun daftar lalu membuat skala prioritas koleksi yang akan segera dicari dan ditempatkan pada aplikasi OER Perpustakaan IAIN Curup. Pustakawan kemudian membuat daftar subjek sesuai kebutuhan informasi dari sejumlah program studi yang ada. Kebutuhan subjek dapat dipetakan menggunakan alat seleksi, contohnya dokumen di program studi Rencana Program Semester (RPS). Pustakawan melalui RPS dapat mengidentifikasi subjek yang dibahas pada mata kuliah tertentu. Kemudian pustakawan membuat daftar subjek pada masing-masing mata kuliah. Pada tahap ini, pustakawan membuat daftar subjek kebutuhan koleksi atau informasi sumber pembelajaran terbuka yang disusun secara alfabetis.

Tahap perencanaan kedua, ialah identifikasi. Tahap identifikasi adalah tahap paling penting dari semua tahapan perencanaan OER. Pustakawan dalam tahap ini melakukan proses pencarian dokumen berdasarkan kata kunci yang bersumber dari subjek yang telah tersusun. Pustakawan mengumpulkan dan mengidentifikasi lokasi sumber informasi bahan pembelajaran terbuka yang tersedia. Pustakawan kemudian menelusur sumbersumber tersebut untuk menemukan sumber informasi yang dibutuhkan sesuai daftar yang diperoleh pada tahap analisis kebutuhan.

Pustakawan lalu dapat mengunduh, mengumpulkan informasi (harvesting) yang dibutuhkan, dan mengelompokkan informasi sesuai format. Sumber informasi pembelajaran terbuka saat ini memang sudah tersedia dalam banyak format dan bentuk. Ada beberapa bentuk dan format bahan pembelajaran terbuka berbentuk file dokumen yang diproduksi aplikasi pengolah kata dan pengolah data, seperti Microsoft Word, WPS Office, Microsoft Excel, Microsoft Powerpoint, dan lain-lain. Bentuk file dokumen ialah file yang memiliki extension, misalnya Doc, doc $x, p d f, x l s, x l s x$, dan lain-lain. Selain itu, ada bentuk file audio berupa file yang berisi rekaman suara, musik, pidato, ceramah, atau bahkan audiobook. Semua file ini biasanya memiliki format WAV, mp3, aud, amr, dan sebagainya. Adapun bentuk file video, adalah konten yang diambil dari platform media sosial YouTube dan sejenisnya. File ini memiliki kapasitas lumayan besar sehingga membutuhkan ruang penyimpanan yang ekstra. File video biasanya memiliki ekstension mp4, wmv, flv, 3gp, dan lain-lain. File hasil unduhan dikelompokkan berdasarkan format dan subjek.

Tahap perencanaan ketiga yaitu tahap verifikasi koleksi. Pustakawan setelah mengumpulkan koleksi lalu melakukan verifikasi untuk melihat jenis lisensi dari koleksi tersebut. Berdasarkan definisi OER sendiri, koleksi OER dapat dikategorikan sebagai koleksi yang memiliki lisensi Creative Common (CC), sebagai organisasi nirlaba yang didedikasikan untuk 
membangun komunitas pengetahuan dan budaya yang dapat diakses secara global. Koleksi EOR yang berlisensi CC dapat memudahkan pemustaka membagikan karya kreatif dan akademik, mengakses, membangun karya, membantu pemustaka lain, mengorganisasikan penyebaran ilmu pengetahuan, dan menumbuhkan kreativitas untuk mengembangkan masyarakat yang lebih adil dan inovatif.

Lisensi CC sendiri memiliki pembagian dalam kategori lisensi di antaranya, pertama atribusi (attribution, A, " $B Y$ "), di mana pemustaka memiliki kewajiban memasukkan nama yang cocok, memasukkan informasi terhadap lisensi, dan memasukkan pernyataan seandainya ada perubahan. Pengembang dapat menerapkan label yang sesuai dengan bentuk informasi dengan memberi izin kepada pengguna untuk memanfaatkan isi. Kedua, Berbagi Serupa (share-alike, BS, "SA"), di mana berlaku jika suatu karya diganti, digubah, dan dibuat turunannya. Karya yang diganti, diubah, atau ciptaan turunan dari karya yang dibuat maka pengembang wajib memberlakukan lisensi yang sama apabila karya asli menerapkan dan menggunakan ketentuan ini.

Kedua, Non Komersial (noncommercial, $\mathrm{NK}$, “NC"), di mana pemakai ciptaan tidak diperbolehkan menggunakan hasil ciptaan sumber pembelajaran terbuka untuk tujuan dan kepentingan komersial. Ketiga, Tanpa Turunan (no derivative works, noderivs, $\mathrm{TKT}$, “ND”), di mana pemakai hasil ciptaan tidak diperbolehkan mengumumkan setiap hasil ubahan atau pembuatan ciptaan turunan dari asli penciptanya. Setelah koleksi hasil penelusuran sudah dipastikan jenis lisensinya yang mendukung $O E R$, tahap selanjutnya adalah pengorganisasian.

Model pengelolaan OER kedua, tahap pengorganisasian yang berisi 1 langkah, yaitu pengolahan yang mengacu pada standar pengelolaan koleksi bahan pustaka. Pada tahap ini pustakawan memasukkan data koleksi ke dalam aplikasi OER.

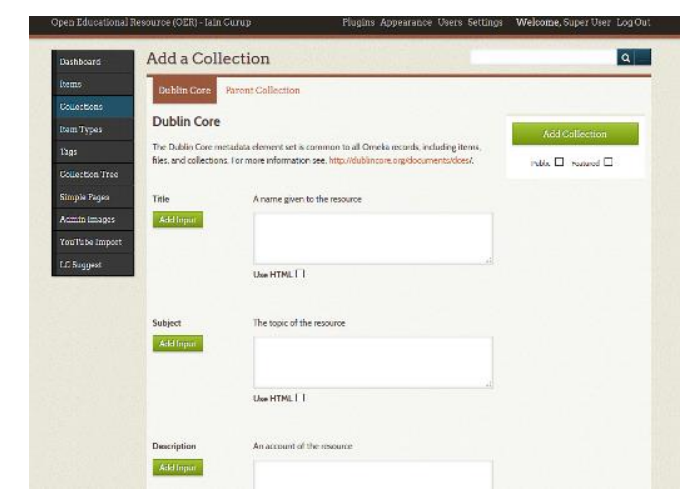

Gambar 2. Tahap pengolahan koleksi EOR Sumber: Institut Agama Islam Negeri Curup, 2020

Sesuai gambar 2, pustakawan harus mengisi beberapa ruas data sebagai metadata koleksi, di antaranya title, subject, discription, creator, source atau publisher, dan date. Ruas title, ialah ruas yang diisi judul koleksi dan ditulis menggunakan kaidah standar pengatalogan. Ruas subject dapat diisi fokus atau bahasan utama dari koleksi. Ruas discription, menjelaskan material pembawa dokumen. Ruas creator adalah data tentang pembuat karya. Ruas source atau publisher ialah data tentang penerbitan apabila karya ini pernah dipublikasikan. Ruas date diisi informasi tanggal, bulan, dan tahun karya dibuat atau dipublikasikan. Ruas lainnya mencakup pemasok, hak cipta, relasi, bentuk, bahasa, tipe, alat identifikasi, dan pemeliharaan.

Model pengelolaan OER ketiga, actualizing yang terdiri dari 2 langkah, layanan dan promosi. Setelah pustakawan selesai memasukkan koleksi bahan pembelajaran terbuka ke dalam aplikasi dan membuat alat telusur, maka pustakawan selanjutnya melayankan 
koleksi ke pemustaka. Pada kegiatan layanan, pustakawan melakukan tugasnya untuk memberikan layanan kepada pemustaka mengenai praktik menggunakan layanan OER yang tersedia. Maka pustakawan menyediakan fasilitas teknologi informasi dan memberikan bimbingan dalam pemanfaatan $O E R$ di perpustakaan secara berkesinambungan.

Setelah itu, pustakawan
mempromosikan layanan EOR di perpustakaan. Promosi perpustakaan merupakan tugas pokok dan fungsi pustakawan yang bertujuan memberikan informasi, ajakan, dan himbauan kepada pemustaka dalam menggunakan layanan perpustakaan yang tersedia. Pustakawan dapat membuat poster, spanduk, baliho, atau memanfaatkan media sosial sebagai media promosi. Media sosial sendiri sekarang sebagai alat yang sangat ampuh untuk meningkatkan kinerja promosi. Maka, pustakawan dalam melakukan kegiatan promosi harus berkelanjutan agar pemanfaatan layanan OER secara maksimal.

Model pengelolaan OER keempat adalah tahap evaluasi, di mana model yang dibuat dilaksanakan pada setiap langkah. Tahapan evaluasi adalah tahapan penilaian terhadap seluruh tahapan pengelolaan OER yang bertujuan memberikan nilai terhadap kegiatan yang sedang dilakukan. Pustakawan dalam tahap ini melakukan evaluasi pada tahapan analisis kebutuhan, identifikasi, verifikasi, pengolahan, layanan, dan promosi. Pada pelaksanaannya pemustaka diharapkan dapat melakukan evaluasi secara simultan saat proses berjalan. Peneliti contohkan salah satu instrumen analisis kebutuhan berdasarkan evaluasi perlu diperbaiki maka pustakawan harus langsung dapat memperbaiki. Demikian juga pada langkah yang lainnya.

Produk model manajemen yang dibuat peneliti selanjutnya dinilai para ahli. Adapun ahli yang dilibatkan dalam proses penilaian, terdiri dari ahli bidang manajemen, ahli bidang kepustakawanan, dan ahli bidang teknologi informasi. Berdasarkan hasil penilaian ahli manajemen, model manajemen OER Perpustakaan IAIN Curup dinyatakan baik. Hal ini dilihat dari hasil penilaian yaitu 41 dibagi dengan 10 adalah 4,1, artinya produk sudah baik namun ada beberapa catatan. Hasil penilaian dari ahli kepustakawanan menyatakan bahwa model manajemen OER Perpustakaan IAIN Curup baik. Hal ini terlihat dari hasil penilaian yaitu 39 dibagi 10 adalah 3,9, artinya produk sudah baik namun ada beberapa catatan. Selain itu, hasil penilaian dari ahli kepustakawanan menjelaskan bahwa model manajemen OER Perpustakaan IAIN Curup baik. Hal ini dilihat dari hasil penilaian yaitu 42 dibagi dengan 10 adalah 4,2, artinya produk sudah baik namun ada beberapa catatan.

Maka, untuk melihat efektivitas model manajemen OER, penulis melakukan pengujian yang melibatkan 2 sisi pemustaka dan pelaksana layanan OER. Pada sisi pemustaka, peneliti melihat sejauh mana efektivitas layanan yang diterima pemustaka sedangkan dari sisi pustakawan, peneliti melihat bagaimana manajemen pelaksanaan pelayanan OER dapat dilaksanakan secara efektif. Selain itu, pustakawan dalam melayankan OER kepada pemustaka telah dinilai oleh ahli kepustakawanan.

Kemudian peneliti menggunakan indikator dari Sugiyono (2016) untuk menganalisis efektivitas model manajemen yang dirancang dengan range nilai 1-5 kepada pustakawan ahli. Hasil penilaian 
menyatakan bahwa model manajemen OER Perpustakaan IAIN Curup telah efektif, dilihat dari hasil penilaian yaitu 39 dibagi 10 adalah 3,9, artinya produk dianggap efektif. Adapun hasil data pemustaka terhadap layanan OER, maka layanan OER Perpustakaan IAIN Curup adalah 4,23 yang berarti bernilai efektif. Berdasarkan hasil penelitian yang dilakukan dari beberapa tahap hingga penyempurnaan produk, model manajemen OER Perpustakaan IAIN Curup telah disosialisasikan melalui beberapa kegiatan. Kegiatannya antara lain forum kegiatan pendidikan pemustaka yang diikuti para ahli dalam pengembangan produk, pustakawan yang menjalankan produk layanan OER, dan pemustaka sebagai pemustaka layanan.

\section{SIMPULAN}

Perpustakaan

IAIN Curup

mengembangkan layanan OER dan menyediakan sumber informasi bagi sivitas akademika melalui pengembangan model manajemen yang telah melalui uji kebutuhan pemustaka dan pendapat para ahli yakni menggunakan aplikasi Omeka. Model manajemen OER dibangun sesuai kebutuhan kondisi lembaga, yaitu lembaga pendidikan yang memiliki kekuatan sumber dana dan kekayaan intelektual institusional sehingga OER dilayankan secara terbuka atau open access. Walaupun demikian, model manajemen OER Perpustakaan IAIN Curup belum memiliki kekuatan sumber daya yang baik dan masih memiliki keterbatasan kekayaan intelektual institusi. Adapun penerapannya sendiri bernilai efektif karena telah disesuaikan dengan tahapan pengelolaan proses pembinaan koleksi perpustakaan. Pustakawan pun tidak mengalami kendala dalam memasukkan data. Selain itu, pemustaka yang menggunakan layanan OER menunjukkan bahwa telah mudah mengakses dan melakukan pencarian terhadap koleksi yang diinginkan. Aplikasi OER memungkinkan sebuah perpustakaan mengembangkan pengelolaan koleksi digital sesuai kebutuhan masing-masing perpustakaan. Perpustakaan yang memiliki karakteristik serupa dengan kondisi Perpustakaan IAIN Curup dapat menggunakan model manajemen sebagaimana yang dikembangkan melalui penelitian ini. Aplikasi OER Perpustakaan IAIN Curup dapat diakses melalui website di alamat http://oer.iaincurup.ac.id. Perpustakaan melalui platform open source ini dapat menambahkan fitur tertentu seperti, fitur pencarian, statistik pemakaian, dan lain-lain. Penelitian dilakukan dari tahap uji validasi kebutuhan layanan OER melalui FGD, kemudian dikuatkan menggunakan angket yang disampaikan kepada pemustaka IAIN Curup. Langkah selanjutnya, dilakukan tes uji coba produk dan penyempurnaan produk, berupa model manajemen OER Perpustakaan IAIN Curup. Model pengelolaan OER di Perpustakaan IAIN Curup memiliki beberapa tahapan yang harus dilakukan, di antaranya tahap perencanaan atau persiapan, tahap pengorganisasian, tahap pengelolaan dan pelayanan (actualizing), dan tahap evaluasi. Tahap perencanaan terdiri dari 3 langkah, yaitu analisis kebutuhan, identifikasi, dan verifikasi. Kedua tahap pengorganisasian yaitu pengolahan yang pelaksanaannya mengacu pada standar pengelolaan koleksi bahan pustaka pada umumnya. Ketiga tahap pelayanan yang terdiri dari promosi dan layanan. Terakhir adalah tahap evaluasi, di mana peneliti 
melakukan evaluasi pada model yang yang telah dilaksanakan di setiap langkah. Perpustakaan mensosialisasikan produk ini melalui forum kegiatan pendidikan pemustaka yang diikuti para ahli yang terlibat dalam pengembangan produk, pustakawan yang menjalankan produk layanan $O E R$, dan pemustaka. Hasil penelitian ini masih harus dilakukan evaluasi secara objektif dan terarah. Peneliti pada tahap penelitian selanjutnya akan menilai fenomena layanan OER pada Perpustakaan IAIN Curup melalui evaluasi program. Penelitian tersebut dilakukan menggunakan penelitian deskriptif kualitatif melalui data yang sesuai sehingga perpustakaan dapat melakukan pengembangan secara keberlanjutan. Perpustakaan IAIN Curup selalu berusaha memperbaiki layanan dalam pemenuhan kebutuhan informasi pemustaka sesuai permasalahan dan kendala dalam penerapan OER.

\section{DAFTAR PUSTAKA}

Abeywardena, I. S., \& Gajaraj, D. (2012). OER in Asia: Trends and issues. Policy Forum for Asia and the Pacific: Policy and Practices in Open Educational Resources, 1-4. Retrieved from https:// www.researchgate.net/publi cation/236170573_OER_in_Asia_Tren ds_and_Issues

Adji, S. S. (2014). Pemanfaatan Open Educational Resources (OER) pada pembelajaran online tentang pemanasan global dan perubahan iklim. Seminar Nasional Riset Inovatif II, 245-258. Retrieved from

https:/ / eproceeding.undiksha.ac.id/i ndex.php/senari/article/view/457/3 16

Akbar, A., \& Noviani, N. (2019). Tantangan dan solusi dalam perkembangan teknologi pendidikan di Indonesia. Prosiding Seminar Nasional Pendidikan Program Pascasarjana Universitas PGRI Palembang 03 MEI 2019, 18-25. Retrieved from https://jurnal.univpgripalembang.ac.id/index.php/Prosidin gpps/article/view/2927/2764

Asmad, C. C., Mathar, T., Akbar, K., Arifin, N., Hijrana, Haruddin, ...Satriani. (2018). Tren perkembangan open access institutional repository pada perguruan tinggi di Indonesia. Khizanah Al-Hikmah: Jurnal Ilmu Perpustakaan, Informasi, Dan Kearsipan, 6(2).

https:// doi.org/10.24252/kah.v6i2a8

Fauziyah, N. (2019). Implementasi knowledge management dalam sistem informasi perpustakaan: Studi kasus di Perpustakaan Nasional Republik Indonesia. JIPI: Jurnal Ilmu Perpustakaan Dan Informasi, 4(1), 96105.

https:// doi.org/10.30829/jipi.v4i1.41 23

IFLA. (2019). Open educational resources and libraries. IFLA. Retrieved from https://www.ifla.org/files/assets/cl $\mathrm{m} /$ news/oer_ifla_brief.pdf

Indrajit, R. E. (2018). Pemanfaatan OER dalam kegiatan pembelajaran: Peran transformasional perpustakaan di era digital. Rapat Kerja Nasional FKP2TN Tahun 2018 Berjudul Penguatan Jejaring Untuk Layanan Yang Lebih Baik, 1-43. Retrieved from

http:/ /lib.um.ac.id/index.php/2018/ 03/25/unduh-materi-rapat-kerjatahun-2018-fkp2tn-bangka-belitung/

Irawan, D. E., Abraham, J., Multazam, M. T., Rachmi, C. N., Mulyaningsih, I., Viridi, S., ...Puradimaja, D. J. (2018). 
Era baru publikasi di Indonesia: Status jurnal open access di Directory of Open Access Journal (DOAJ). Berkala Ilmu Perpustakaan Dan Informasi, 14(2), 133-147.

https:/ / doi.org/10.22146/ bip.32920

Irawan, D. E., Rachmi, C. N., Irawan, H., Abraham, J., Kusno, K., Multazam, M. T., ...Aziz, N. A. (2017). Penerapan open science di Indonesia agar riset lebih terbuka, mudah diakses, dan meningkatkan dampak saintifik. Berkala Ilmu Perpustakaan Dan Informasi, 13(1), 25-36. https:/ / doi.org/10.22146/bip.17054

Iswanto, R., \& S. (2018). Prospek pusat informasi dan perpustakaan dalam perkembangan Information and Communication Technology (ICT): Tinjauan komprehensif nilai filosofi ilmu informasi dan perpustakaan. Tik Ilmeu: Jurnal Ilmu Perpustakaan Dan Informasi, 2(1), 55-70.

https:/ / doi.org/10.29240/tik.v2i1.398

Kristyanto, D. (2019). Perpustakaan digital dan kelompok pengguna potensial. Khizanah Al-Hikmah: Jurnal Ilmu Perpustakaan, Informasi, Dan Kearsipan, 7(2), 130-140.

https:/ / doi.org/10.24252/kah.v7i2a4

McGreal, R. (2013). Commonwealth of learning: Creating, using and sharing open educational resources. Commonwealth of Learning. Retrieved from

http://oasis.col.org/bitstream/handl e/11599/44/acqaccredi.pdf?sequence $=1$

Mtebe, J. S., \& Raisamo, R. (2014). Challenges and instructors' intention to adopt and use open educational resources in higher education in Tanzania. IRRODL: The International Review of Research in Open and Distance
Learning, 15(1), 249-271.

https://doi.org/10.19173/irrodl.v15i1 .1687

Muganda, C. K., Samzugi, A. S., \& Mallinson, B. J. (2016). Analytical insights on the position, challenges, and potential for promoting OER in ODeL Institutions in Africa. International Review of Research in Open and Distributed Learning, 17(4), 36-49. https:/ / doi.org/10.19173/irrodl.v17i4 .2465

Mulyadi, Zulkarnain, I., \& Laugu, N. (2019). Adaptasi pustakawan dalam menghadapi kemajuan teknologi. Berkala Ilmu Perpustakaan Dan Informasi, 15(2), 163-174.

https:/ / doi.org/10.22146/bip.39843

Undang-Undang Republik Indonesia Nomor 12 Tahun 2012 Tentang Pendidikan Tinggi. 10 Agustus 2012. Lembaran Negara Republik Indonesia Tahun 2012 Nomor 158. Jakarta. Retrieved from

https:/ /ldikti8.ristekdikti.go.id/wpcontent/uploads/2019/02/Undang Undang_Nomor_12_Tahun_2012_Pen didikan_Tinggi.pdf

Richer, T., \& McPherson, M. (2012). Open educational resources: Education for the world? Distance Education, 33(2), 201-219.

https:/ / doi.org/10.1080/01587919.20 12.692068

Riyanto, S., Marlina, E., \& Triasih, H. (2019). Librarian role in research library services in Indonesian institute of sciences. Berkala Ilmu Perpustakaan Dan Informasi, 15(2), 201-212. https:/ / doi.org/10.22146/bip.35200

Rosyid, M. (2019). Urgensi perpustakaan kampus sebagai media keterbukaan informasi publik dalam mencerdaskan bangsa. Libraria: Jurnal 
Perpustakaan, 7(2), 267-269.

https:/ / doi.org/10.21043/libraria.v7i 2.6511

Setiawan, E. P., \& I. (2018). Penggunaan internet sebagai sumber informasi dalam penyusunan karya ilmiah Siswa SMA Negeri 8 Yogyakarta. Jurnal Kajian Informasi \& Perpustakaan, 6(2), 169-182.

https://doi.org/10.24198/jkip.v6i2.1590

Srirahayu, D. P. (2019). User analysis of library usage to fulfill information needs. Khizanah Al-Hikmah: Jurnal Ilmu Perpustakaan, Informasi, Dan Kearsipan, 7(2), 115-121.

https:// doi.org/10.24252/kah.v7i2a2

Sugiyono. (2016). Metode penelitian kuantitatif, kualitatif dan $R \quad \mathcal{E} D$.
Bandung: Alfabeta.

Sukardjo. (2012). Evaluasi pembelajaran semester 2. Yogyakarta: PPs Universitas Negeri Yogyakarta.

Suwarno, W. (2014). Memperbincangkan penerapan open acces untuk koleksi institusional repository. Jurnal Perpustakaan Libraria, 2(1), 14-28. Retrieved from

https://journal.iainkudus.ac.id/index .php/Libraria/article/view/1187/1080

Wibowo, T. O. (2019). Strategi pengelolaan jurnal akses terbuka menggunakan Open Journal System (OJS). Berkala Ilmu Perpustakaan Dan Informasi, 5(1), 101-113.

https:/ / doi.org/10.22146/bip.38504 